\title{
Indicator-Based Assessment for Soil Resource Management in the Wroclaw Larger Urban Zone of Poland
}

\author{
Szymon Szewrański ${ }^{1}$, Jan Kazak ${ }^{1 *}$, Romuald Żmuda², Rafał Wawer ${ }^{3}$ \\ ${ }^{1}$ Wrocław University of Environmental and Life Sciences, Department of Spatial Economy, \\ ul. Grunwaldzka 55, 50-357 Wrocław, Poland \\ ${ }^{2}$ Wrocław University of Environmental and Life Sciences, Institute of Environmental Protection and Development, \\ pl. Grunwaldzki 24, 50-363 Wrocław, Poland \\ ${ }^{3}$ Institute of Soil Science and Plant Cultivation, Department of Soil Science Erosion and Land Conservation, \\ ul. Czartoryskich 8, 24-100 Puławy, Poland
}

Received: 10 November 2016

Accepted: 3 April 2017

\begin{abstract}
This article presents a discussion about the issue of soil resource management in the context of sustainable development. These resources are one of the basic resources on Earth, conditioning the sustainable development of present and future generations by providing the capacity for food production. The study contains an indicator-based assessment of changes in available soil resources as a result of progressive urbanization processes in the suburban area of a big city. The case study was the Wrocław Larger Urban Zone in Poland. The applied methodology allowed for the valorization of urban sprawl processes on agricultural land. As a result, municipalities were divided into groups that characterize different suburbanization processes and their impact on the available soil resources. By using the proposed approach, it is possible to support the spatial development management process in order to protect the valuable components of the environment. The results of the research show that 29 rural precincts located around Wrocław have a high soil transition index $(\mathrm{W} \geq 50)$, which proves their inefficient agricultural management system on a regional scale. The study is an attempt to answer a question on the practical implementation of sustainable development goals that were included in Agenda 2030.
\end{abstract}

Keywords: soil resources, suburbanization, environmental management, indicator-based assessment of environmental changes, Wrocław Larger Urban Zone

*e-mail: jan.kazak@upwr.edu.pl 


\section{Introduction}

The number of soils used for agriculture is constantly decreasing. The phenomenon is not exclusively observed in Poland but considered a global tendency [1]. The area of land used for urbanization, transportation, and industry is steadily growing [2]. The annual land take in European countries assessed by the 2006 Corine Land Cover project was approximately 108,000 ha/year. More arable land and permanent crops were taken by artificial development than before 2000. The mean annual urban land take as a percentage of total urban land take in Poland was $2,981 \mathrm{ha} /$ year, or $2.8 \%$ share of Europe's total land take [3]. The night lights spatial data retrieved for Poland indicate that the process occurring there over the last few years is much faster than in other countries [4].

The phenomenon of dwindling soil resources in Poland and their degradation is a result of designating soil for housing developments, as well as transportation and industrial land. The process of suburbanization, which significantly alters the structure of soil use in suburban areas, is intensifying. This is especially apparent in the case of the Larger Urban Zone of the City of Wrocław [5-6]. Modern agglomerations shall adapt to climate change as well as improve their metabolic resilience both in the environmental and socio-economic dimensions. Urban systems need to use resources more efficiently, generate more resources within their borders, and diversify sources of water, food, energy, and materials [7]. Good and sustainable governance at a local level requires solid data collection and analytical toolsets for a better assessment of available water resources [8-9], its management $[10,11]$, and flood risks and loss assessments [12-13]. New, integrated approaches for food production and distribution management shall be developed and applied due to suburban arable land declining [14-15]. Energy flows and materials produced and consumed by urban ecosystems shall be recognized and understood for better local planning and urban design [16-17]. The soilwater system remains the crucial element of the ecological framework on which food production and water resource management depend directly [18-20].

Efficient mitigation of spatial-functional conflicts resulting from the implementation of often disparate ecological, economic, and social interests should be one of the strategic goals of managing soil resources. This is especially important in the wake of new challenges related to adapting to climate change, losing biological diversity [21-22], or cultural landscape conservation [23]. PanEuropean research shows that changes in land use have multiple causes and are characterized by different time and space dynamics. It has been pointed out that the EU must reconcile the need for supra-national uniformity and local adaptation of policies. Therefore, European policy should be place-based and spatially targeted [24-25]. In land and soil protection policy implementation, land owners and local policy makers will play a key role [26]. The results of environmental studies for spatial planning purposes became supported in recent years more often by
GIS, which is useful, for instance, in drainage systems assessment [27] or soil erosion evaluation [28]. The results of spatial analysis enables a better decision-making process [29] and, therefore, supports local and regional management. GIS-based methods are extremely useful in monitoring spatial changes in metropolitan areas [30].

Complex internal determinants, dynamic shifts in the environment, and the multi-aspect nature of economic and environmental processes create the need to assume an integrated approach to simultaneously managing development and environmental protection. The system of managing the environment is most often founded on the Deming Cycle PDCA [plan-do-check-act] model [31]. An active approach to management requires establishing and utilizing proper GIS tools, variant modelling, and impact projection systems, as well as multi-criteria analyses and decision support systems [32-33]. The process of defining strategic goals and action programming should be carried out exclusively based on scientific proof and knowledge [34]. Thus, a properly devised integrated soil resource management system should ensure an incessant cycle of conducting research and monitoring the impact of decisions made in this domain [35]. Implementation of land protection strategies is particularly important in areas of dynamic changes such as the peripherals and suburbia of towns and cities.

The decision support system developed by Marinoni et al. [36] was used to design and locate a new housing development. Based on spatial data, hydrological information, multi-criteria analysis, and the GIS visualisation system, the pollutant loads of flowing surface water were computed. The decisions made with the use of the model were based on scenario analysis. The authors noticed that the presented environmental assessment tool should be extended by a social and economic dimension. Such GIS-based multi-criteria land suitability analysis was designed by Nguyen et al. [37]. Data on agricultural, ecological, and socio-economic conditions are combined together within a mathematical assessment procedure that includes standardized scoring, weighting, fuzzy membership assignment, and Boolean logic. The final results are presented as overall land suitability classes. The mixed socio-environmental approach to the assessment of urban resilience to climate change was proposed by Krellenberg et al. [38]. Local adaptive capacity would be evaluated within a three-step process based on residential vulnerability and socio-environmental fragmentation. Fragmentation is indicated by the percentage of impermeable surface area as well as the percentage of surface area with vegetation cover. Increasing urban expansion causes the depletion of soil resources and declining local crop production. An agricultural land use planning tool was developed by Pilehforooshha et al. [39]. According to the land demand assessment and suitability evaluation model, a mapping of agricultural and crop land allocation is proposed. Therefore, a key tool for supporting decisions in these areas are solid and reliable socio-economic and spatio-environmental indicators. 
Skog and Steinnes [40] had defined farmland conversions as agricultural land take and changes in land use from farmland to built-up land. The aim of GIS analysis carried out in Norway was to understand how urban sprawl impacts agricultural land take. Between 2008 and 2015, $56 \%$ of farmland conversion took place within urban administrative borders. About $20 \%$ of transformations occurred in periurban zones, and only $23 \%$ of farmland conversions where recorded in rural areas. Almost 75\% of converted farmland had been fully cultivated before transformation. Economic losses had been assessed on approximately 45,000 tons of grain per year.

Ferrara et al. [41] analyzed soil loss impacted by longterm urban expansion in the agricultural region of northern Italy. The quantitative data of land transformations had been enriched by information on soil quality based on parent material, soil depth, texture, and slope angle. During our research we studied the surface of land under different building densities, as well as the soil quality index (SQI) [42]. Between 1945 and 2001, the share of non-urbanized land declined from $11.8 \%$ to $6.3 \%$. The authors concluded that urbanization had consumed soils with progressively higher quality. During 1945-1971, fertile soils had been transformed into compact and dense built-up areas. Since 1971, high quality soils have been mostly occupied by discontinuous and low-density settlements. The results showed an increasing mismatch between agricultural land use and the utilization of high-quality soils. Data exploration proved that the measurement of permeable land development alone is an insufficient indicator of soil resource loss.

Colantoni et al. [43] investigated suburbanizationdriven land take in Athens, Greece, during 1987-2007. The authors evaluated selective land take for cropland, sparsely vegetated areas, and natural land. The selective land take indicator revealed a disproportion between utilized land resources and their availability. The share of built-up areas increased from $13.2 \%$ to $18.1 \%$ during the research period. The data illustrated that primarily cropland and sparse vegetation areas had been transformed into urban zones. Agricultural land decline positively depending on population growth and density, and mostly appeared at a distance of 5 to $15 \mathrm{~km}$ from the inner city. The authors identified agricultural land as the primary sufferer of unsustainable urban sprawl and concluded that planning tools are ineffective for mitigating the process of selective land take.

The land consumption indicator was originally proposed by Salvati [44] as the ratio of two proportions: percentage of surface area of the same class consumed by urbanization during a time period to the percentage of surface area of a specific class in the non-urban landscape at the starting time. The indicator value ranges from 0 (no land take due to urbanization) to 1 (land consumption proportional and adequate to availability). Salvati's research was carried out in Rome's suburban settlements and concerned the years 1949-2008. The highest decline of $-25 \%$ was recorded on arable lands. The consumption index calculated for this class ranged from 9.9 to 1.1 .
Land consumption of pastures, mixed cropland, urban parks, arable land. And vineyards was higher than their percentage share in the landscape.

Mantas et al. [45] developed an integrated land change monitoring system for Mondego River watershed management. Based on Landsat products, NDVI time series, regression tree models, and land transformations change vector analysis (CVA), a new impervious surface area (ISA) indicator was proposed. ISA represents the impervious land share within a pixel. Sub-pixel mapping of soil sealing was originally proposed by Yang et al. [46]. Both research methods proved that high accuracy data analyses of the spatial change of an impervious surface is a useful indicator for urbanization assessment.

The integration of three dimensions of the amount of built-up area, settlement dispersion, and spatial configuration, as well as the uptake of built-up area per capita, was proposed by Jaeger and Schwick [47]. Weighted urban proliferation (WUP) was developed for urban sprawl monitoring and assessment. The authors applied their method to evaluate sprawl in Switzerland. Between 1935 and 2002, suburbanization increased by $155 \%$. A further increase of more than $50 \%$ is projected by 2050 .

The soil transition index was developed to evaluate the impact of land consumption on soil resources. The indicator illustrates simultaneously the direction of land cover flows and the depletion of different soil classes. It allows for the monitoring of high-quality agricultural soil losses caused by settlement development, proportionally to the share of this class in total soil cover. The combination of quantitive and qualitive assessments provides a complex overview on environmental impact and helps to improve soil conservation measures [48].

\section{Materials and Methods}

The aim of this article is to assess the environmental impact of new settlement development in a suburban zone. The indicator-based evaluation of high urban pressure on soil resources depletion was carried out with a combined quantitative and qualitative analysis (Fig. 1). The assessment has been performed on the basis of the following spatial data:

- Soil map with a reference scale of 1:25000 (updated in 2010).

- CORINE Land Cover land use designation map for 1990, 2000, and 2006, with a reference scale of $1: 100,000$.

- Geodetic precincts border map with a reference scale of $1: 2,000$.

Geospatial data had been projected in the coordinate system PL EUREF89 1992. The original IUNG's soil map was updated in 2010 in a scale of 1:5,000, and then generalized to $1: 25,000$.

The research was conducted using a stage approach. The following layers have been retrieved at the first stage: 


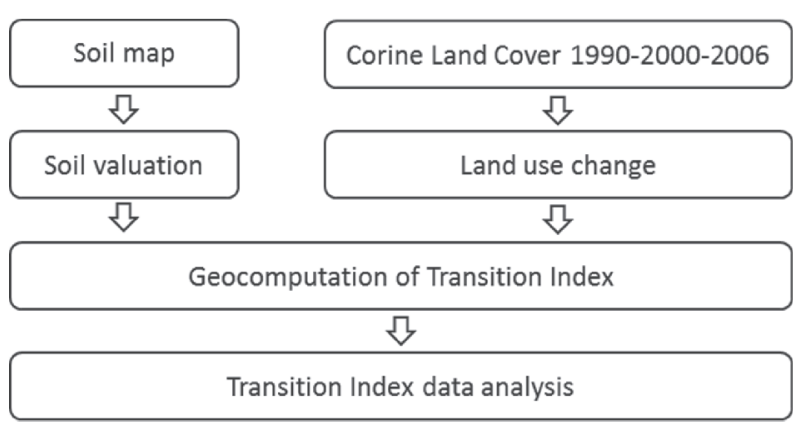

Fig. 1. Conceptual model of the research framework.

- Changes in soil use in the years 1990-2000.

- Changes in soil use in the years 2000-2006.

- Changes in soil use in the multiannual period of 19902006.

The next stage involved intersecting the abovementioned maps with a soil map, which allowed us to attain quantitative data for the changes of use with regard to each specific type, order, and agricultural soil complex. The evaluation of agricultural areas was achieved with the use of a method developed at the IUNG in Puławy. The valuation uses a range from 1 to 100 points according to soil-specific, climatic, and land conditions [49]. The classification (Table 1) was carried out based on a framework of complexes of agricultural soil suitability [50].

The resulting three layers have been generalized by dividing the agricultural soil complexes into three groups:

Table 1. Evaluation of agricultural areas [51].

\begin{tabular}{|c|c|c|}
\hline $\begin{array}{l}\text { Agricultural soil suitability } \\
\text { complexes }\end{array}$ & $\begin{array}{c}\text { Point } \\
\text { valuation }\end{array}$ & $\begin{array}{l}\text { Fertility } \\
\text { groups }\end{array}$ \\
\hline 1 Very good wheat complex & 94 & \multirow{10}{*}{$\begin{array}{l}\text { Highly } \\
\text { fertile } \\
\text { and } \\
\text { fertile }\end{array}$} \\
\hline 2 Good wheat complex & 80 & \\
\hline $1 z$ Very good and good grasslands & 80 & \\
\hline 10 Mountain wheat complex & 75 & \\
\hline 4 Very good rye complex & 70 & \\
\hline 8 Good cereal-fodder complex & 64 & \\
\hline 3 Poor wheat complex & 61 & \\
\hline 11 Mountain cereal complex & 61 & \\
\hline 5 Good rye complex & 52 & \\
\hline 2z Moderate grasslands & 50 & \\
\hline 9 Poor cereal-fodder complex & 33 & \multirow{3}{*}{$\begin{array}{l}\text { Average } \\
\text { fertile }\end{array}$} \\
\hline 12 Mountain oat-potatoes complex & 33 & \\
\hline 6 Poor rye complex & 30 & \\
\hline $3 z$ Poor and very poor grasslands & 20 & \multirow{3}{*}{$\begin{array}{l}\text { Low } \\
\text { fertile }\end{array}$} \\
\hline 7 Very poor rye complex & 18 & \\
\hline 13 Mountain oat-fodder complex & 18 & \\
\hline
\end{tabular}

highly fertile and fertile soils, soils of average fertility, and low fertility soil. Three soil fertility ranges using point values from the valuation indicator have been established using the production environment agricultural valuation indicator for agricultural soil complexes:

- Highly fertile and fertile soils $-\geq 50$ valuation indicator.

- Soils of average fertility $-<50$ and $\geq 30$ valuation indicator.

- Low-fertility soil $-<30$ valuation indicator.

An additional class with no determined valuation indicator value was created apart from the basic three fertility classes, including areas excluded from mapping on the soil map and representing forests, built-up areas, wasteland, roads, etc. Soil loss resulting from land development has been assessed with the use of a transition index that combines both land use flow as well as agricultural soil suitability and its potential productivity. The soil transition index (TI) is calculated as the ratio of the share of a given soil class within the transformed area to the share of this class in the total soil cover [48].

Transition Index $(\mathrm{TI})=\frac{\% \text { of soil class } n \text { in new built area }}{\% \text { of soil class } n \text { in whole urban area }}$

The authors presupposed a simplified interpretation of the calculated values. Sustainable land management can be observed when the TI is lower than 0.8 for $\mathrm{W} \geq 50$ highquality soils, as well as higher than 1.2 for low-quality $\mathrm{W}<30$ soils. Data out of this range stands for unsustainable trends in land development. A detailed discussion on TI calculation can be found in the deliverables of the urban SMS project [52].

The study area is the city of Wrockaw and 10 surrounding communes: three urban-rural communes (Katty Wrocławskie, Siechnice, and Oborniki Śląskie) and seven rural communes (Kobierzyce, Żórawina, Czernica, Długołęka, Wisznia Mała, Miękinia, and Kostomłoty)

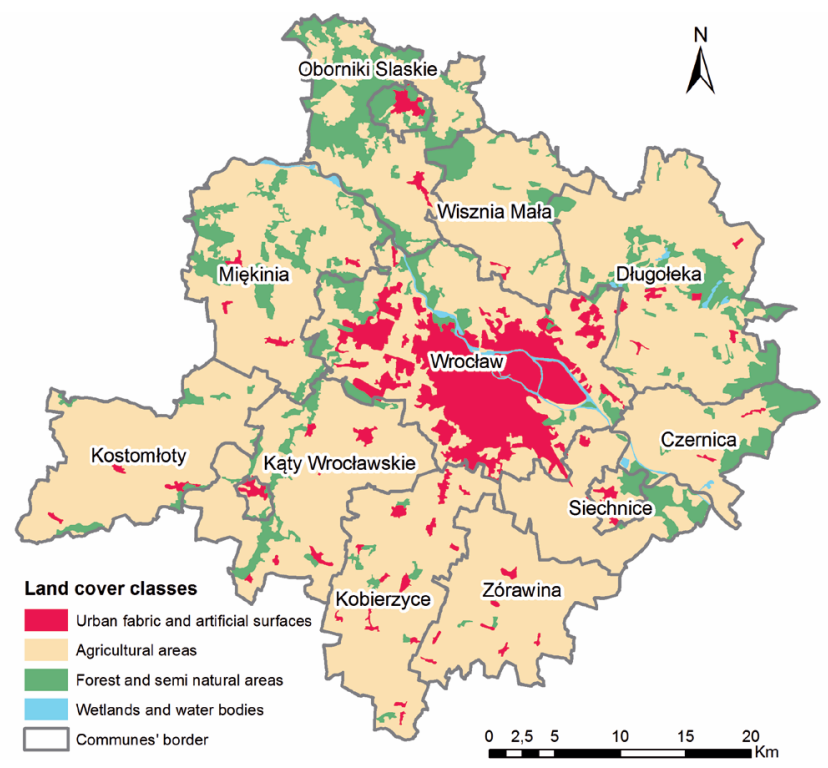

Fig. 2. Land cover of study area. 
(Fig. 1); Oborniki Śląskie and Wisznia Mała are part of Trzebnica County; Miękinia and Kostomłoty are part of Środa Śląska County; and the rest of the communes are part of Wrocław County. The city of Wroclaw is an independent administrative unit. In 1990, the total area was inhabited by 755,148 people. During the research period, the population of Wrocław decreased by 8,588 inhabitants while the population of the surrounding communes rose by 16,936 people. In 1990 , the share of agricultural lands (including pastures and plantations) ranged from 58.4\% (Oborniki Śląskie) to $97.4 \%$ (Żórawina). In Wrocław it was $46.7 \%$ of the total area. Broad-leaved and coniferous forest covered from $0.6 \%$ (Żórawina) to $38.0 \%$ (Oborniki Śląskie) of the total commune's area. In the core city, the afforestation rate was 9.3\%. Urbanised area (including industrial and technical infrastructure) ranged from $0.5 \%$ (Wisznia Mała) to $4.8 \%$ (Kobierzyce) of the land cover. In Wrocław urban fabric covered $36.2 \%$ of the municipal area. The highest share of water-related land cover was noticed in Czernica as well as in Wrocław. The average values for the whole study area were: agricultural land cover $76.6 \%$, afforestation $13.5 \%$, built-up areas $7.9 \%$, and others $2.0 \%$.

Natural conditions vary over the research area and contain 10 Natura2000 areas and three other legal forms of environmental protection areas. According to the landforms, most of the area represents a river valley with one main river (the Odra) and four smaller ones that end in the main one, and the northern part is covered by hills. Due to the described landforms, the majority of the study area is lowlands, which guarantee good conditions for urban development from an investment cost perspective.

\section{Results and Discussion}

\section{The Soil Resources of the Wrocław Larger Urban Zone}

With regard to the geological-structural character, the Wrocław Larger Urban Zone is located on the border between two large geological units, i.e., the Fore-Sudetic Block and the Fore-Sudetic Monocline. The topographical relief had almost exclusively developed in the quaternary. The soil formations fit the category of lowland and upland areas and are the result of glacial tills and fluvioglacial landforms, as well as alluvial formations mostly comprised of sand, clay, silt deposits, of aquatic origin, and loess formations. The main type of soil include brown, acid brown, and lessive.

Wrocław county and city are a central part of the studied area, characterized by a low typological diversity of soils. Black soils cover the largest area in this county $(41.52 \%)$, followed by lessive (20.33\%), alluvial (19.56\%), and brown (17.94\%) soils. The contribution of soils of other types should at most be considered symbolic. They are considered to represent various complexes with regard to agricultural suitability.

The data described above clearly indicate that the agricultural land in the county is predominantly used as arable land. Grasslands constitute as little as 15.07\% of the total agricultural land area, a major part of which $(11.14 \%)$ is covered with medium-quality soil. The lands are mostly located in the valley of the Oder and the valleys of its tributaries. Areas for urbanized terrain are mostly set aside with their role in the environment resulting from the habitat functions they serve. $85 \%$ of the arable land in the Wrockaw county area is agricultural land. This area is covered with soils of the highest agricultural suitability complexes, i.e. the very good wheat complex and the poor wheat complex, c. $58 \%$ of which is agricultural land in this county (Fig. 2).

The best soils (very good wheat complex (1)) are mostly black soils. The soils of this complex in the county cover c. $24 \%$ of the agricultural land area. Soils from the second best complex (the good wheat complex) cover the largest area in Wrocław County, i.e., more than 34\%. The percentage share of soils of other agricultural suitability complexes is significantly lower and does not reach $10 \%$ in the context of each specific complex. The largest areas of this group represent the good rye complex (5), the poor wheat complex (3), the poor rye complex (6), and the very good rye complex (4).

The agricultural lands of Trzebnica County are characterized by a relatively low typological soil diversity. The largest area (c. 34\%) is covered by soils classified as lessive. About $24 \%$ is covered by alluvial soils, followed by more than $28 \%$ of brown soils and $11 \%$ covered by black soils. The remaining types of soils have but a symbolic share in the area of agricultural land. The
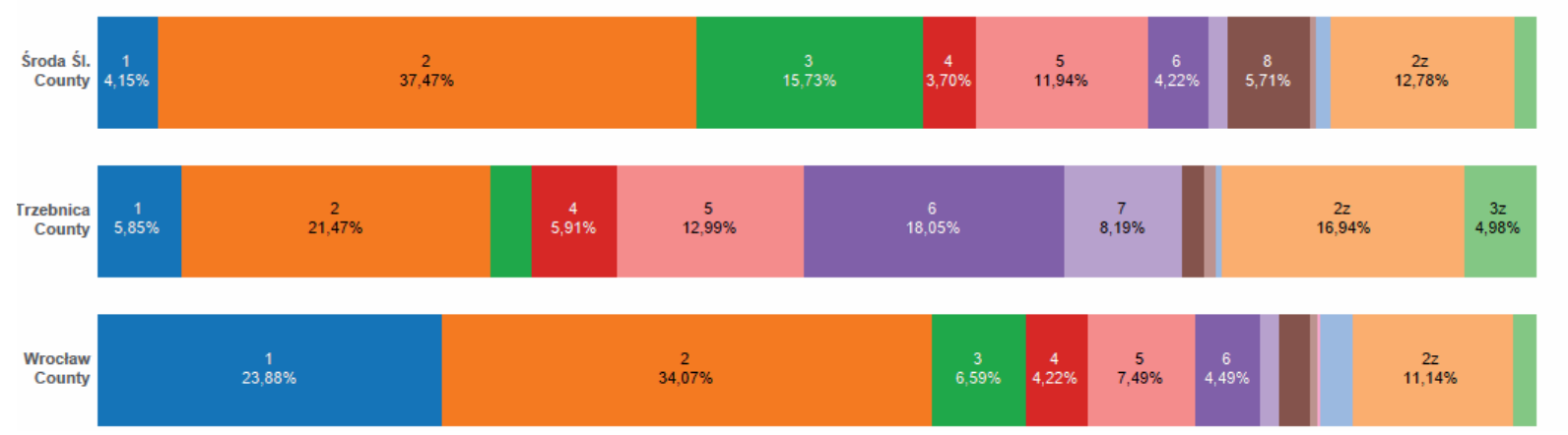

Fig. 3. Soil complexes in the Wrocław Larger Urban Zone. 
dominant method of agricultural land use is for arable land. The physiographic conditions of the county and the presence of forest areas result in a significantly larger share of grasslands. More than $22 \%$ (22.27\%) of meadows and pastures are used for agriculture. The largest area among them is used for medium-complex grasslands located mostly in the valleys of smaller watercourses. Grasslands of the lowest class (poor and very poor) with a low level of agricultural significance and suitable for afforestation or ecological use depending on habitat-related determinants, represent a significant contribution of c. $5 \%$.

Arable land of the highest complex (1) cover only c. $6 \%$. The largest share (c. $22 \%$ ) is that of soils from the good wheat complex. Soils from the good rye complex (5) and the poor rye complex (6) have a high percentage share of c. $13 \%$ and c. $18 \%$, respectively. Agricultural land in Trzebnica County is characterised by a high percentage share of soil from the very poor rye complex (over $8 \%$ ). These soils, formed from highly permeable host rocks (loose and loamy sands with a shallow foundation of, e.g., gravel) are characterized by a very low agricultural suitability and should be used for other functions in the spatial management of Trzebnica County.

The soils of Środa Śląska County are also characterized by a low typological diversity. The largest area in this county is comprised of brown soils, with $40 \%$ of agricultural land. The second largest area is that of lands with lessive soils (c. 29\%), alluvial soils (c. $19 \%$ ), and black soils (10\%). The remaining types of soils do not exceed a contribution level of $1 \%$ in the area of agricultural land. Agricultural land in Środa Śląska County is predominantly used as arable land. Grasslands can be found mostly in watercourse valleys, including the Odra and smaller watercourses. Soils of the good wheat complex (2) cover a very large area of agricultural land (c. 37\%). Soils classified as representative of the poor wheat complex (3) cover a relatively large area of $\mathrm{c}$. $16 \%$, with c. $12 \%$ covered by soils from the good rye

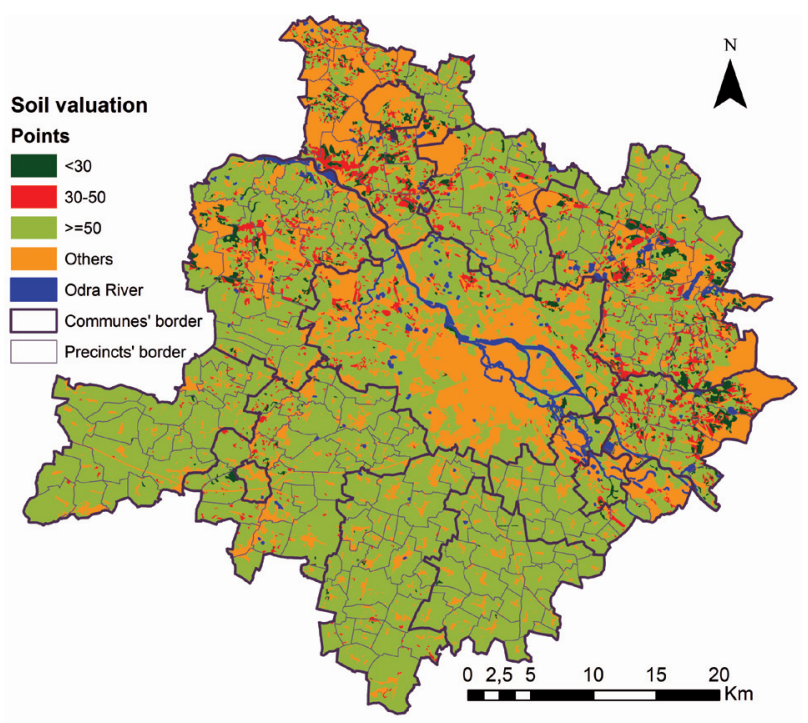

Fig. 4. Soil valuation in the research area. complex (5). Środa Śląska County also contains soils from the best soil suitability complex, i.e., the very good wheat complex (1). Areas with such soils slightly exceed $4 \%$ of the total agricultural land area.

The above determinants allow for a detailed valuation of soils covering the studied area with regard to soil fertility (Fig. 3). The analysis has been conducted on the level of geodetic precincts. Its results have been represented on an agricultural soil valuation map with a scale of $1: 350,000$.

Analysis of the fertility values of the soils in the study area clearly indicates that the largest areas covered with soils of the highest fertility and valuation indicator exceeding 50 points are generally located south of the Oder. This includes practically all the precincts of Katy Wrocławskie commune, where areas of highest fertility constitute c. $90 \%$ of the agricultural land as evaluated using the above classification. All the qualified precincts of Kobierzyce commune contain a similarly high percentage of soils of the highest fertility of between c. $80 \%$ to over $90 \%$. More than $90 \%$ of soils of the highest fertility in the neighbouring commune of Żórawina can be found in two precincts, and four in Siechnice commune.

The communes of Czernica and Długołęka, eastern neighbours of Wrocław city, had slightly lower fertility of soils, with only six units being considered as precincts with soils of the highest fertility rate.

On its western side, Wrocław city neighbours the lands of Miękinia commune in Środa Śląska County. From among all the qualified precincts in this commune, only two are characterized by the highest fertility values.

To the north, Wrocław city is surrounded by lands from Wisznia Mała and Oborniki Śląskie communes, which are part of Trzebnica County. The most fertile soils on this side can be found in the southern part of the county. The lands of Oborniki Śląskie commune can be considered as weaker.

\section{The Effects of Utilization and Suburbanization}

The analysis of the fertility values of the soils indicated that the areas located to the south of Wrocław city offer the best conditions for the functioning of agriculture in this respect. Taking into account the agroclimatic conditions, the area can be considered as suitable for intensive agriculture. The northern areas lack such values, yet one may still find occasional precincts offering highly fertile soil.

The development of the Wrocław Larger Urban Zone has had a tangible impact on the soil environment. Due to the changes in use, circa $23 \%$ of silt loams and about $22 \%$ of medium silty loams have been lost in 2006 when compared to the amount from 1990. A relatively large area has also been transformed into a built-up area with soil orders such as loamy sands (14\%) and heavy loamy sands $(9 \%)$. The area subject to the total amount of land use change exceeds 1,400 ha.

With regard to typological soil classification, the classes 
of soils lost due to transformations from agricultural land to built-up areas in the multiannual period of 1990-2006 mainly involved proper black soil (23\%), podsolic and pseudopodsolic (20\%), as well as a major part of proper brown soils (14.5\%) and black degraded soils (12\%). A major loss was seen by proper alluvial soils (7\%) and leached and acidic brown soils (5\%).

In terms of agricultural suitability, the highest loss rate has been noted for soils considered to represent some of the best arable land complexes, i.e. the good wheat complex (2) at $26 \%$ and the very good wheat complex (1) at $13 \%$. A similarly significant loss has been noted as a result of this type of land use for soils classified as representative of the poor wheat complex (3) at 92 ha, the good rye complex (5) at 122 ha, the poor rye complex (6) at 97 ha, the very poor rye complex (7) at $74 \mathrm{ha}$, and the very good rye complex (4) at more than 57 ha. Some loss has also been noted for soils covering grasslands. Due to transformations to builtup areas, more than $8 \%$ of medium-quality grasslands ( 2 z complex) have been lost.

Local government actions in the area of agricultural land protection and soil resource management have been evaluated from the point of view of rational management of soil resources. The index of transforming agricultural soil into built-up areas served as a tool used to assess these actions. The results of the evaluation of transforming land in accordance with the methodology described above have been represented using small multiple maps (Fig. 4).

In the years 1990-2000, the use of terrains in the Wrocław Larger Urban Zone for purposes of construction most often involved areas with low significance for agriculture, i.e., wastelands, etc. The precincts subjected to high urban pressure were located alongside the old National Road No. 8 to Warsaw, as well as around the Highway A4 node in both directions to Cracow and Dresden. In almost all of these precincts, most of the valuable areas $(\mathrm{W} \geq 50)$ were relatively rarely designated for construction. An exception to this was Źórawina, where the agricultural land protection practices were proven to be far from perfect. The precincts located in Długołęka commune serve as an example of very good practices and a proper approach to protecting agricultural land, as the lands most often designated for construction in these sections were that with the weakest soils with
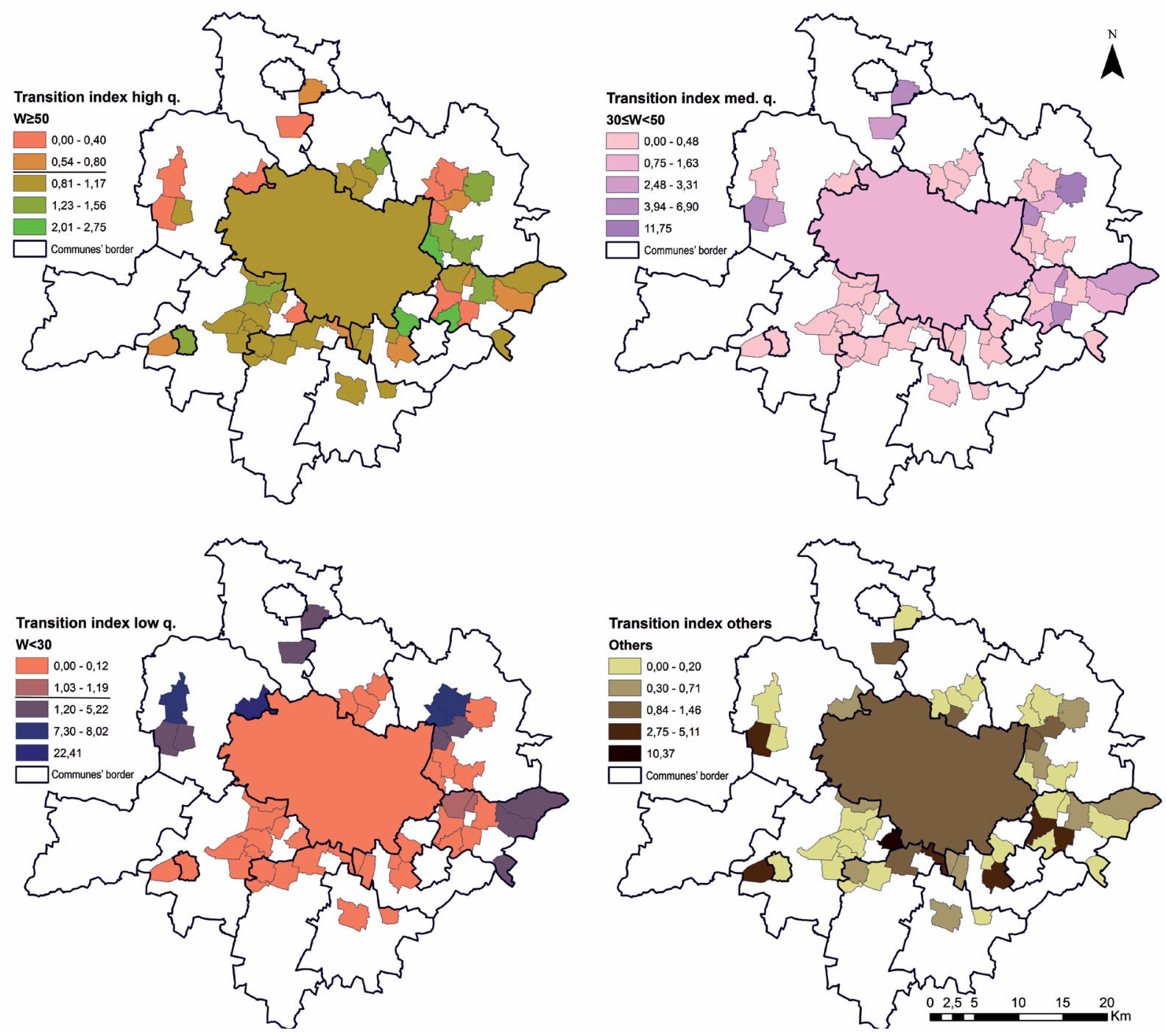

Fig. 5. Indicators of agricultural land transition in the years 1990-2006. 
low suitability for agriculture, i.e., with a $\mathrm{W}<30$ valuation index.

In the following years (2000-06) the process of entering the European Union served as a stimulus for the dynamic development of the WLUZ. The pressure to acquire more land for construction and the increasing significance of single-family housing led to a series of negative spatial changes. Social pressure led to the exclusion of lands covered with the most valuable soil from agricultural use. The highest degree of using such unsustainable practices has been noted in precincts located alongside the main roads leading out of Wrocław city.

Miękinia commune should serve as a model of good practice in soil management. The lands most often designated for construction in Miękinia are those of the lowest suitability for agriculture $(\mathrm{W}<30)$. The land governance policy pursued in the Wilkszyn Precinct stands out from all other sections, as its index of agricultural land transformation for construction exceeds 22. A favourable situation is also noticed in some precincts located in Oborniki Śląskie commune. The lowest fertile soil transformation into settlement developments had been noticed in the afforested precincts or in the neighboring Odra River valley.

The above analysis for the multiannual period of 19902006 clearly indicates that the practice of using lands considered most valuable for agriculture with the highest and medium levels of fertility is becoming increasingly common (Fig. 5).

Improper soil management practices throughout the timespan of several years have been noted mostly in sections located in the eastern side of the Wrockaw Larger Urban Zone. Examples of poor agricultural land management (group D, see Fig. 6) on the northern side

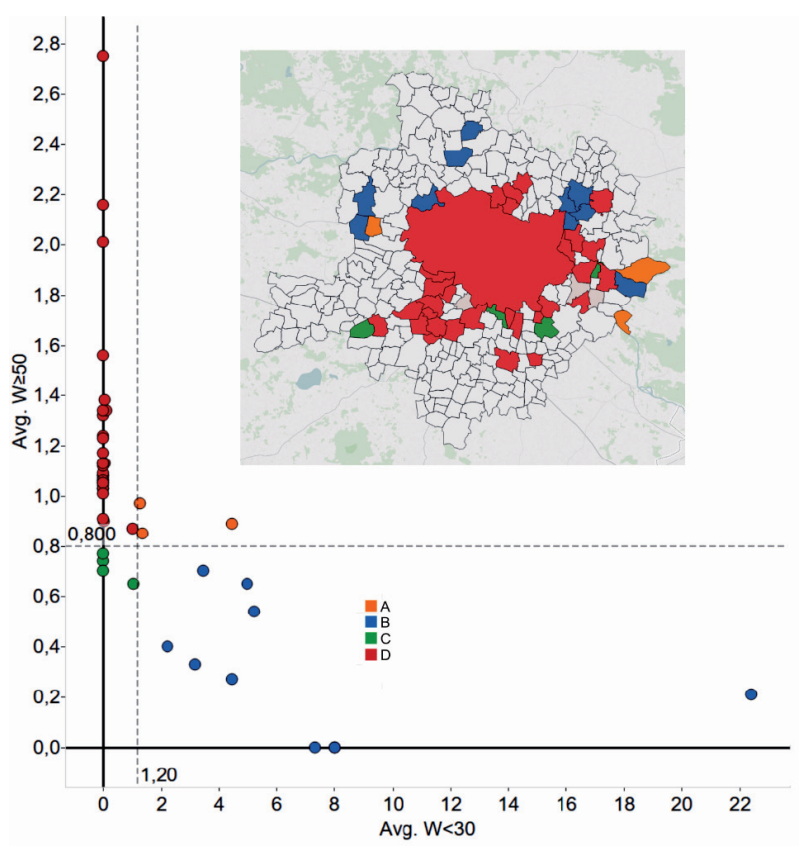

Fig. 6. The average indexes of the high- $(\mathrm{W} \geq 50)$ and low-quality $(\mathrm{W}<30)$ agricultural soils transitioning into built-up areas. include the precincts located alongside the main road to Poznań. To the south, the sections that represent inproper management of the most fertile soils are concentrated around highway and freeway exits and nodes. Precincts to the west of Wrocław are characterized by a relatively sustainable agricultural land economy. The best lands in these precincts are rarely excluded for construction purposes, with soils of medium or poor fertility being more commonly chosen instead. Examples of proper spatial management of agricultural land are characterized by the $\mathrm{W}<30$ valuation indicator (group B). The spatial policy pursued in Miekkinia commune should serve as a model for all other sections.

In the Urban SMS project [52], the relationship between soil resource conservation and land consumption had been studied within the municipal borders of: Milan, Bratislava, Prague, Wrocław, Stuttgart, Vienna, and Salzburg. Ex-post evaluation of land changes in the years 1990-2007 had been carried out with the use of the soil transition index. The results showed that the transformation into urban fabrics takes place mostly on arable lands. In Vienna, Wrocław, Prague, and Salzburg, urbanization occurred on the most valuable soils, disproportionally. The transition index calculated for the best soils ranged from 1.29 to 3.01. In Stuttgart and Milan, the pattern of land consumption had been proportional to landscape composition. The most valuable soils had been protected in Bratislava. The transition index for these soils was calculated at the level 0.21 . The transition index evaluation in this paper was made within the same thresholds of 0.8 and 1.2 values as in the original Urban SAS project. Indexes for the transition of soils of different quality into the sealed area for Wroclaw city between 1991 and 2006 were as follows: for high-quality soils $\mathrm{TI}=1.33$, medium-quality $\mathrm{TI}=0.68$, and low-quality TI $=0.69$. We decided to use it unmodified to ensure the comparability and complementarity of the spatial data. Aggregated results at commune level showed that the highest index for the best soils was in Siechnice $(\mathrm{TI}=1.33)$ and Wisznia Mała $(\mathrm{TI}=1.12)$. The lowest index values had been noticed in Miękinia $(\mathrm{TI}=0.35)$ and Oborniki Śląskie (TI =0.47). The transition index for medium soils varied from 0.03 (Wisznia Mała) to 3.41 (Oborniki Ślaskie). For the low-quality soils, the index ranged from 1.26 (Czernica) to 8.56 (Miękinia).

\section{Conclusions}

In summary, the above analyses of soil resources and the agricultural values of specific precincts bordering the Wrocław Larger Urban Zone and located in its vicinity, it should be stated that suburbanization should be directed toward sections located north of the Oder and Wrocław, as well as to the east. According to soil resources, the areas suitable for this purpose should include terrains located in Oborniki Śląskie commune to the north, which lack high agricultural value. In terms of physiographic and natural features, this terrain can be considered as recreational agricultural regions. The second direction 
for the development of the Wrocław Larger Urban Zone should include terrain to the east and sections that are part of Długołęka commune, which offer a relatively small amount of soils from the highest classes. The eastern precincts of Miękinia commune should mark the border of Wrocław expansion. Our research shows that:

- The city should not expand southwards, as that is where one will find areas of the highest value to agriculture, which has soil fertility values and agroclimatic conditions that place them in the category of areas of intensive agricultural development.

- Spatial policy and resource management should be directed toward the protection of soils used for agriculture as well as limiting the expansion of builtup areas to an unavoidable minimum.

- Every commune provides its own development policy regardless of sub-regional environmental aspects.

- Effective soil resource protection requires intergraded policy-making on a sub-regional scale.

The considerations presented in this article contribute to the practical implementation of a number of the demands of sustainable development as defined in Agenda 2030 [53], which contains 17 Goals for Sustainable Development. It is currently the most current action program defining the sustainable development paradigm at the global level. According to the agenda, contemporary modernization efforts should focus on: achieving food security, ensuring healthy living conditions, construction of safe and sustainable cities and human settlements, conservation and sustainable use of land ecosystems, and reversing the process of degradation and loss of biodiversity. Implementation of this policy should be based on the principle of using the best available knowledge. Building evidence-based policy requires, in turn, carrying out continuous monitoring of environmental changes and the involvement of all stakeholders in the decisionmaking process. According to the provisions of Agenda 2030, space should be planned and managed with the participation of citizens in the spirit of good governance and in decision-making. One of the changes involves the reduction of residents' pressure on the environment, especially in residential areas. These ambitious targets are to be reached by 2030 . The practical implementation of sustainable development policies requires making a series of decisions based on reliable data and indicatorbased assessments. The suggestions in this article are the basis for further discussion on the suitability of aggregated indicators illustrating qualitative and quantitative soil transformation.

\section{References}

1. SETO K.C., FRAGKIAS M., GÜNERALP B., REILLY M.K. A Meta-Analysis of Global Urban Land Expansion. PLoS ONE. 6 (8), e23777, 2011.

2. HENNIG E.I., SCHWICK C., SOUKUP T., ORLITOVÁ E., KIENAST F., JAEGER J.A.G. Multi-scale analysis of urban sprawl in Europe: Towards a European de-sprawling strategy. Land Use Policy. 49, 483, 2015.
3. EEA. Land take. Report, EEA, Brussels 2013.

4. STATHAKIS D., TSELIOS V., FARASLIS I. Urbanization in European regions based on night lights. Remote Sensing Applications: Society and Environment. 2, 26, 2015.

5. KAZAK J., SZEWRANSKI S., DECEWICZ P. Holistic Assessment of Spatial Policies for Sustainable Management: Case Study of Larger Urban Zone (Poland). [In:] D.,J. Lee et al. (Eds.) Geodesign by Integrating Design and Geospatial Sciences, GeoJournal Library 1, 71, 2014.

6. HEŁDAK M., RASZKA B., SZCZEPAŃSKI J. Design of Ground Surface Sealing in The Spatial Policy of Communes. Procedia Engineering. 161, 1367, 2016.

7. ROSE J.F.P. The well-tempered city : what modern science, ancient civilizations, and human nature teach us about the future of urban life, New York, NY, Harper Wave. 2016.

8. VALIPOUR M. How much meteorological information is necessary to achieve reliable accuracy for rainfall estimations? Agriculture. 6, 53, 2016.

9. VALIPOUR M., GHOLAMI SEFIDKOUHI M.A., RAEINISARJAZ M. Selecting the best model to estimate potential evapotranspiration with respect to climate change and magnitudes of extreme events. Agricultural Water Management. 180, Part A, 50, 2017.

10. VALIPOUR M. A Comparison between Horizontal and Vertical Drainage Systems (Include Pipe Drainage, Open Ditch Drainage, and Pumped Wells) in Anisotropic Soils. IOSRJMCE IOSR Journal of Mechanical and Civil Engineering. 4, 7, 2012.

11. VALIPOUR M. Use of surface water supply index to assessing of water resources management in Clorado and Oregon, US. Advances in Agriculture, Sciences and Engineering Research. 3, 631, 2013.

12. OLSEN A.S., ZHOU Q., LINDE J.J., ARNBJERGNIELSEN K. Comparing methods of calculating expected annual damage in urban pluvial flood risk assessments. Water (Switzerland). 7, 255, 2015.

13. HAMMOND M.J., CHEN A.S., DJORDJEVIĆ S., BUTLER D., MARK O. Urban flood impact assessment: A stateof-the-art review. Urban Water Journal. 12, 14, 2015.

14. ARMENDÁRIZ V., ARMENIA S., ATZORI A. Systemic Analysis of Food Supply and Distribution Systems in CityRegion Systems-An Examination of FAO's Policy Guidelines towards Sustainable Agri-Food Systems. Agriculture. 6, 65, 2016.

15. OLSSON E., KERSELAERS E., SØDERKVIST KRISTENSEN L., PRIMDAHL J., ROGGE E., WÄSTFELT A. Peri-Urban Food Production and Its Relation to Urban Resilience. Sustainability. 8, 1340, 2016.

16. ROSADO L., KALMYKOVA Y., PATRÍCIO J. Urban metabolism profiles. An empirical analysis of the material flow characteristics of three metropolitan areas in Sweden. Journal of Cleaner Production. 126, 206, 2016.

17. CONKE L.S., FERREIRA T.L. Urban metabolism: Measuring the city's contribution to sustainable development. Environmental Pollution. 202, 146, 2015.

18. PORKKA M., GERTEN D., SCHAPHOFF S., SIEBERT, S., KUMMU M. Causes and trends of water scarcity in food production. Environmental Research Letters. 11 (1), 2016.

19. JÄGERMEYR J., GERTEN D., SCHAPHOFF S., HEINKE J., LUCHT W., ROCKSTRÖM J. Integrated crop water management might sustainably halve the global food gap. Environmental Research Letters. 11 (1), 2016.

20. AMUNDSON R., BERHE A.A., HOPMANS J.W., OLSON C., SZTEIN A.E. SPARKS D.L. Soil and human security in the 21 st century. Science. 348, 647, 2015. 
21. STOATE C., BÁLDI A., BEJA P., BOATMAN N.D., HERZON I., VAN DOORN A., DE SNOO G.R., RAKOSY L., RAMWELL C. Ecological impacts of early 21ST century agricultural change in Europe - A review. Journal of Environmental Management. 91 (1), 22, 2009.

22. HOFMANN M.E., HINKEL J., WROBEL M. Classifying knowledge on climate change impacts, adaptation, and vulnerability in Europe for informing adaptation research and decision-making: A conceptual meta-analysis. Global Environmental Change. 21 (3), 1106, 2011.

23. HERNIK J., GAWROŃSKI K., DIXON-GOUGH R. Social and economic conflicts between cultural landscapes and rural communities in the English and Polish systems. Land Use Policy. 30, 800, 2013.

24. COISNON T., OUESLATI W., SALANIÉ J. Spatial targeting of agri-environmental policy and urban development. Ecological Economics. 101, 33, 2014.

25. COISNON T., OUESLATI W., SALANIÉ J. Urban sprawl occurrence under spatially varying agricultural amenities. Regional Science and Urban Economic. 44, 38, 2014.

26. KRISTENSEN S.B.P. Agriculture and landscape interactionlandowners' decision-making and drivers of land use change in rural Europe. Land Use Policy. 57, 759, 2016.

27. ESKANDARI S., HOSSEINI S. A. Assessment of Drainage System Standards of Forest Roads in Iran Using GIS. Polish Journal of Environmental Studies. 22, 675, 2013.

28. ZIVOTIC L., PEROVIC V., JARAMAZ D., DORDEVIC A., PETROVIC R., TODOROVIC M. Application of USLE, GIS, and Remote Sensing in the Assessment of Soil Erosion Rates in Southeastern Serbia. Polish Journal of Environmental Studies. 21, 1929, 2012.

29. HOU K., LI X.X., WANG J.J., ZHANG J. Evaluating Ecological Vulnerability Using the GIS and Analytic Hierarchy Process (AHP) Method in Yan>an, China. Polish Journal of Environmental Studies. 25, 599, 2016.

30. GUTRY-KORYCKA M. Urban sprawl: Warsaw agglomeration : case study. Warsaw University Press. 2005.

31. PETROSILLO I., DE MARCO A., BOTTA S., COMOGLIO C. EMAS in local authorities: Suitable indicators in adopting environmental management systems. Ecological Indicators. 13 (1), 263, 2012.

32. CARSJENS G., LIGTENBERG A. A GIS-based support tool for sustainable spatial planning in metropolitan areas. Landscape and Urban Planning. 80, 72, 2007.

33. COTTER M., BERKHOFF K., GIBREEL T., GHORBANI A., GOLBON R., NUPPENAU E.-A., SAUERBORN J. Designing a sustainable land use scenario based on a combination of ecological assessments and economic optimization. Ecological Indicators. 36, 779, 2014.

34. MAUELSHAGEN C., SMITH M., SCHILLER F., DENYER D., ROCKS S., POLLARD S. Effective risk governance for environmental policy making: A knowledge management perspective. Environmental Science \& Policy. 41, 23, 2014.

35. DUBEL A., JAMONTT-SKOTIS M., KRÓLIKOWSKA K., STEFAŃSKA J., BANROWSKA A. The effective management of Natura 2000 sites. Stowarzyszenie CRS, GS Kraków. 2010.

36. MARINONI O., HIGGINS A., COAD P., NAVARRO GARCIA J. Directing urban development to the right places: Assessing the impact of urban development on water quality in an estuarine environment. Landscape and Urban Planning. 113, 62, 2013.
37. NGUYEN T.T., VERDOODT A., VAN Y.T., DELBECQUE N., TRAN T.C., VAN RANST E. Design of a GIS and multicriteria based land evaluation procedure for sustainable landuse planning at the regional level. Agriculture, Ecosystems \& Environment. 200, 1, 2015.

38. KRELLENBERG K., LINK F., WELZ J., HARRIS J., BARTH K., IRARRAZAVAL F. Supporting local adaptation: The contribution of socio-environmental fragmentation to urban vulnerability. Applied Geography. 55, 61, 2014.

39. PILEHFOROOSHHA P., KARIMI M.,TALEAI M. A GISbased agricultural land-use allocation model coupling increase and decrease in land demand. Agricultural Systems. 130, 116, 2014

40. SKOG K. L., STEINNES M. How do centrality, population growth and urban sprawl impact farmland conversion in Norway? Land Use Policy. 59, 185, 2016.

41. FERRARA A., SALVATI L., SABBI A., COLANTONI A. Soil resources, land cover changes and rural areas: Towards a spatial mismatch? Science of The Total Environment, 478, 116,2014

42. European Environment Agency. Soil quality index map. http://www.eea.europa.eu/data-and-maps/figures/soilquality-index-map, 2009.

43. COLANTONI A., GRIGORIADIS E., SATERIANO A., VENANZONI G., SALVATI L. Cities as selective land predators? A lesson on urban growth, deregulated planning and sprawl containment. Science of The Total Environment. 545-546, 329, 2016.

44. SALVATI L. Land availability vs conversion by use type: A new approach for land take monitoring. Ecological Indicators. 36, 221, 2014.

45. MANTAS V.M., MARQUES J.C., PEREIRA A.J.S.C. A geospatial approach to monitoring impervious surfaces in watersheds using Landsat data (the Mondego Basin, Portugal as a case study). Ecological Indicators. 71, 449, 2016.

46. YANG L., XIAN G.Z., KLAVER J.M., DEAL B. Urban land-cover change detection through sub-pixel imperviousness mapping using remotely sensed data. Photogrammetric Engineering and Remote Sensing. 69, 1003, 2003.

47. JAEGER J.A.G., SCHWICK C. Improving the measurement of urban sprawl: Weighted Urban Proliferation (WUP) and its application to Switzerland. Ecological Indicators. 38, 294, 2014.

48. STUCZYŃSKI T. Assessment an modelling of land use change in Europe in the context of soil protection. IUNG Pulawy. 2007.

49. BIAŁOUSZ S., MARCINEK J., STUCZYŃSKI T., TURSKI R. Soil Survey, Monitoring and Databases in Poland. [In:] R.J.A. Jones, B. Houšková, P. Bullock and L. Montanarella (Eds.) European Soil Bureau, Research Report No. 9, 2005.

50. TERELAK H., WITEK T. Poland [In:] J.A. Zink (Ed.), Soil Survey: Perspectives and Strategies for the $21^{\text {st }}$ Century, FAO. 1995.

51. WITEK T. Valorisation of agricultural production area. IUNG, Puławy. 1981.

52. SIEBIELEC G., LOPATKA A., STUCZYNSKI T., KOZAK M., GLUSZCZYNSKA M., KOZA J., ZUREK A., KORZENIOWSKA-PUCULEK R. Assessment of Soil Protection Efficiency And Land Use Change. Urban SMS Report. 2010.

53. UN. Transforming our world: the 2030 Agenda for Sustainable Development. A/RES/70/1, 2015. 